\title{
Shakespearean Editing and Why It Matters
}

\author{
Leah Marcus \\ Vanderbilt University
}

\begin{abstract}
A generation ago, many Shakespearean scholars simply accepted the versions of the play that they were provided with by editors. So long as the label was right - Arden, Oxford, Cambridge, Penguin, Riverside, Pelican - the content was assumed to be reliable. But editing can never be transparent - it is always influenced by the cultural assumptions of the editor and his or her era, however submerged those assumptions may be in terms of the editor's stated textual practices. In the late twentieth and twenty-first centuries, as a result of feminist and postcolonial critical approaches to Shakespearean texts, we have begun to realize the degree to which our inherited editions are shaped in accordance with assumptions about colonialism, race, and the status of women that are no longer acceptable to us, and that in fact distort elements of Shakespeare's plays as they exist in early printed quarto and folio versions. As earlier disciplinary boundaries between editing and criticism have broken down, Shakespearean critics have increasingly turned to editing in order to undo some of the racist and sexist assumptions behind our received texts of the plays.
\end{abstract}

A generation ago, many Shakespearean scholars simply accepted the versions of the play that they were provided with by editors. So long as the label was right - Arden, Oxford, Cambridge, Penguin, Riverside, Pelican - the content was assumed to be reliable. One of my colleagues asked me, "What difference does it make whether there were one or two or a hundred early texts of King Lear? I know precisely what every word of the play means."

I responded, "How can you know what every word of King Lear means when the precise wording of the text is different in every edition of the play?"

He answered doggedly, "I know what every word in the play means because I know what every word of the Pelican Shakespeare King Lear means." But is that the same as knowing what the play means? Over time, we have lost our faith that any single meaning can be established for any of the plays, and also that any single text can be claimed as absolutely definitive. By revisiting the traditional editing of Shakespeare, we have been able to recognize ways in which older editions have shaped the plays to accord with the values of their own times - values that may be very different from those of our own period, or even from those of the sixteenth or seventeenth centuries. Often, by questioning the ways in which 
the meanings of the plays have been steered in particular directions by editing, we can open up the plays to a range of possible meanings that traditional editing had shut down.

One example of this tendency is the persistence in modern editions of eighteenth-century cast lists for the plays, which are organized according to social hierarchy, and invariably list all the women characters below the men - so that princesses come after the clowns and fools, and readers are predisposed to regard even the most aristocratic and/or the most central female characters, such as Rosalind in As You Like It, as automatically subordinate to the males. Since none of these lists dates from Shakespeare's own time, and they can scarcely be regarded as mapping out the relative importance of persons within the plays, why not replace them, as some more recent editions have begun to do, with cast lists that introduce readers to characters in the order of their appearance? Or, if an editor feels that a period sense of class difference needs to be preserved, the traditional lists can be replaced with cast lists that integrate women and men in order of their social status.

Within the plays, too, editors have tended to downplay possible instances of female authority, on the supposition that such authority must have been unacceptable in Shakespeare's own time. Of course a formidable and powerful woman - Queen Elizabeth I - was on the throne, but she was assumed to be the exception that proved the rule. Sometimes early Shakespearean editions of the same play offer contrasting constructions of the power and status of female characters, and in those cases editors have traditionally tended to prefer the version that accords women less rather than more authority. For example, in choosing among variant readings in texts of The Merry Wives of Windsor editors have tended to favor the first folio version of the play (1623) over the first quarto version (1602), in which the Windsor wives' interventions to save their families from the jealousy of Mr. Ford and the sexual predation of Falstaff are less compromised by the values of visiting courtiers.

Similarly, in the first quarto version of Hamlet (1603), Queen Gertrude is horrified to hear that her son suspects her of complicity in Hamlet Senior's murder, and assures him that she is innocent and that she will help him in his covert campaign against Claudius. ${ }^{1}$ Would it not be possible for modern editions at least to include in their notes the interpretive possibilities introduced by Gertrude's protestations of innocence and vows of assistance in the first quarto version of the play? Instead most have consigned these speeches to oblivion. In these and many other cases, Shakespearean editors beg the question of women's agency by offering it in diminished range from the start. As a result, critics and other readers are more likely to perceive women's assertion of power and agency in the plays as subversive of order and decorum; they are also more likely to interpret women's functioning in terms of a subversion-containment dynamic that precludes a broader, more flexible, understanding of women's 
roles in the plays and in the culture of which Shakespearean drama formed a part.

Another area in which past editorial shaping of the Shakespearean text is particularly evident is in regard to issues of race and ethnicity. Colonial and postcolonial interpretations of Shakespeare have become mainstream in recent criticism - witness Ania Loomba and Martin Orkin's collection, Post-Colonial Shakespeares, among others. ${ }^{2}$ But postcolonial interpretation does not always take into account the degree to which the Shakespearean editions that have come down to us have already been colonized. At the same time that military men and administrators were consolidating British reign over an expansive empire, Shakespearean editors were tidying up play texts by ridding them of "dangerous" racial anomalies. British administrators were asserting their authority over the "blacks" of India and Africa, and British and American editors were producing Shakespearean editions that enforced subtle distinctions based on race and ethnicity. One example comes from The Tempest, a play that is steeped in issues relating to colonial exploration and conquest. This play does not exist in competing early versions: our only early source for the text of the play is the first folio version (1623). Here, we are dealing not with a choice of one available early text over another, but with editorial intervention through the explanatory notes. The monster Caliban's mother Sycorax, a witch from Algiers, is referred to in the play as a "blue-eyed hag." Unwilling to accept the idea that an alien North-African crone could have eyes of a color that our culture has traditionally associated with beauty and romance, editors have routinely explained to readers that "blue-eyed" in this case means black and blue around the eyes. While there is some evidence that the epithet could have such a meaning in Shakespeare's period, there is also considerable evidence that "blue-eyed" then could mean "with eyes of blue" - a reading that moves Sycorax out of the traditional Anglo-American stereotype of the racialized other and makes it less easier to think of her - and by extension of her son Caliban - in terms of the usual assumptions about race and physical traits. ${ }^{3}$

Another illustrative example comes from Christopher Marlowe's Tamburlaine, which is not a Shakespearean play, but comes from roughly the same period and has been subject to similar editorial pressures. Tamburlaine is a Muslim warrior-hero described in Marlowe's text as "pale of complexion" and amber haired, with "arms and fingers long and snowy." Most modern editors emend "snowy" to "sinewy" on grounds that lily-white skin does not accord particularly well with the image of a Middle Eastern conqueror. But all three of the earliest printed versions of the play agree in the reading, and the fourth early text reads, even more specifically, "snowy-white." ${ }^{4}$ The editorial tradition has suppressed a potentially unsettling similarity in skin and hair color between the barbarous "alien" Muslim and the British who formed the core of Marlowe's early audiences - and probably also the play's core readership during the nineteenth and early twentieth centuries. 
Sometimes the opposite happens: early editions of a play may preserve markers of racial difference that modern editors elide, but that scholars studying a play in its social context would consider valuable evidence. That may be the case for the presentation of Shylock in The Merchant of Venice. The early printed texts are notoriously unstable in terms of their naming of characters, but especially interesting in their naming of Shylock, whose speech prefixes identify him sometimes as "Shylock" and sometimes, generically, as "Jew." In a play that reverberates with antisemitism, it is particularly instructive to see how the speech prefix "Jew" comes to dominate during the trial scene, as Shylock begins to enact primordial stereotypes associated with Jewish blood libels by demanding his pound of flesh from the Christian Antonio. ${ }^{5}$

Another interesting case of editorial suppression of markers of racial difference is Othello, which exists in two early printed forms: a quarto edition of 1622 and the folio edition of 1623 . Given the proximity of the two editions in terms of date, we might suppose that their texts would be similar, but they are not. The quarto does not include most of the speeches that mark Othello as racially other because of his blackness, and as a result, its politics of race is considerably more benign, or at least considerably less developed in establishing skin color as a sign of the usual stereotypes associated with blackness: hypersexuality, barbarity, demonism, and the like. ${ }^{6}$ How are we to interpret this absence? Did Shakespeare write the play in its shorter quarto form and then add the most racially charged elements of the play as part of a later revision? Or did he write the play in its folio form and then remove some of its most (to us) highlycharged associations between blackness and cultural marginality, perhaps for a specific performance? It is not possible to decide this issue by studying the texts themselves, but we need to have access to both versions of the play in our modern editions in order to pursue it further. The days have past when editing can be safely relegated to scholars who are outside the mainstream of Shakespearean criticism. In fact, more and more major critics in the field are becoming editors, because we are coming to recognize how important editing is to the interpretive choices we are able and willing to make as readers and scholars of Shakespeare.

\footnotetext{
Notes

${ }^{1}$ Both of these examples are discussed in L. S. Marcus, Unediting the Renaissance: Shakespeare, Marlowe, Milton (London and New York: Routledge, 1996).

${ }^{2}$ See, for example, A. Loomba and M. Orkin, eds., Post-Colonial Shakespeares (London and New York: Routledge, 1998); C. M. S. Alexander and S. Wells, eds., Shakespeare and Race (Cambridge: Cambridge University Press, 2000). More generally, Loomba, Colonialism/Postcolonialism (London and New York: Routledge, 1998); Robert J. C. Young, Postcolonialism: An Historical Introduction (Oxford: Blackwell Publishing, 2001).

${ }^{3}$ Marcus, Unediting the Renaissance, pp. 5-17. The essay is also available in the Norton Critical Edition of The Tempest, ed. P. Hulme and W. H. Sherman (New York and London: W. W. Norton, 2004), pp. 286-98.
} 
${ }^{4}$ L. S. Marcus, "Marlowe in tempore belli," in War and Words: Horror and Heroism in the Literature of Warfare, ed. Sara Deats et al. (Lanham, Maryland: Rowman and Littlefield, 2004), pp. 295316.

${ }^{5}$ See A. Patterson, ed., The Most Excellent History of the Merchant of Venice (Englewood Cliffs, NJ: Prentice Hall, 1995); J. Shapiro, Shakespeare and the Jews (New York: Columbia University Press, 1996). My Norton Critical Edition of The Merchant of Venice (2005) will preserve the anomalous speech prefixes to make it easier for scholars and students to discuss their possible cultural implications.

${ }^{6}$ See L. S. Marcus, "The Two Texts of Othello and Early Modern Constructions of Race," in Textual Performances: The Modern Reproduction of Shakespeare's Drama, ed. L. Erne and M. J. Kidnie (Cambridge: Cambridge University Press, 2004), pp. 21-36.

\section{Bibliography}

Alexander, C. M. S. and S. Wells, eds., Shakespeare and Race (Cambridge: Cambridge University Press, 2000).

Chartier, R., Forms and Meanings: Texts, Performances, and Audiences from Codex to Computer (Philadelphia: University of Pennsylvania Press, 1995).

Clayton, T., ed., The Hamlet First Published (Q1, 1603): Origins, Form, Intertextualities (Newark: University of Delaware Press; London and Toronto: Associated University Presses, 1992).

Deats, S., et al., eds., War and Words: Horror and Heroism in the Literature of Warfare (Lanham, Maryland: Rowman and Littlefield, 2004).

Erne, L. and M. J. Kidnie, eds., Textual Performances: The Modern Reproduction of Shakespeare's Drama (Cambridge: Cambridge University Press, 2004).

Foucault, M., "What Is an Author?" (1969), in Textual Strategies: Perspectives in Post-Structuralist Criticism, rpt. and trans. J. V. Harari (Ithaca: Cornell University Press, 1979), pp. 141-60.

Loomba, A., Colonialism/Postcolonialism (London and New York: Routledge, 1998).

Loomba, A. and M. Orkin, eds., Post-Colonial Shakespeares (London and New York: Routledge, 1998).

McGann, J. J., A Critique of Modern Textual Criticism (Chicago and London: University of Chicago Press, 1983).

Marcus, L. S., Unediting the Renaissance: Shakespeare, Marlowe, Milton (London and New York: Routledge, 1996).

Patterson, A., ed., The Most Excellent History of the Merchant of Venice (Englewood Cliffs, NJ: Prentice Hall, 1995).

Shapiro, J., Shakespeare and the Jews (New York: Columbia University Press, 1996).

Taylor, G. and M. Warren, ed., The Division of the Kingdoms: Shakespeare's Two Versions of King Lear (Oxford: Clarendon Press, 1983).

Urkowitz, S., Shakespeare's Revision of King Lear (Princeton: Princeton University Press, 1980).

Young, R. J. C., Postcolonialism: An Historical Introduction (Oxford: Blackwell, 2001). 